\title{
Academic Supervision of Principals, School Culture and Teacher Teaching Performance
}

\author{
Shita Sophianingreki \\ Department of Education Management \\ Universitas Negeri Surabaya \\ Surabaya, Indonesia \\ Shita.18017@mhs.unesa.ac.id
}

\begin{abstract}
This study focuses on school principal's academic supervision, school culture on the teaching performance of the Santo Yosef Middle School in Surabaya. Teacher teaching performance is based on three indicators: (1) mastery of teaching materials, (2) ability to manage learning and (3) commitment to carry out tasks. The teaching performance of the teacher is supervised by the principal (academic supervision) through the development of quality learning activities so that it will become a strength of quality quality school culture. The research method uses descriptive analytical methods with quantitative approaches. The results of the data are carried out with "descriptive statistics". The findings of this research are teacher's teaching performance is influenced by these two things, namely school culture and the influence of school principal's academic supervision. Maintaining traditions, values, and habits that strengthen a culture positive school will have an impact on improving the quality of schools.
\end{abstract}

Keywords-academic supervision principals; school culture; teaching performance of teachers

\section{INTRODUCTION}

The community has excessive expectations of the teacher. School success or failure is often addressed to the teacher. The justification of the community is understandable because the teacher is an active resource, while the other resources are passive. Therefore, the best curriculum, facilities, learning facilities and infrastructure, but if the quality of the teacher is low then it is difficult to get high quality educational results. Various efforts can be taken to create good productivity / performance, one of which is to improve the quality of work. Efforts to improve the quality of education are central to all kinds of efforts to improve quality and change education [1]. The quality of teaching problems carried out by the teacher must be continuously and continuously supervised and guided. Supervision in education aims to develop the potential of students through quality learning activities that are served by teachers. Professional supervision of teachers by principals aims to improve teaching skills is called academic supervision. Furthermore, it is said that performance is the result of organizational cultural values which also means that performance is also a manifestation of existing cultural values [2]. Superior quality work and works can be realized if supported by superior quality human resources. The strength of human resources will mean the existence of a school culture. The core value of school culture is usually more philosophical even somewhat similar to emphasizing the quality that is the character of a school.

School culture is a characteristic, character or character and image of the school in the wider community. Collaboration between members has elements of vision and mission, resources, legal basis of structure and anatomy that is clear in order to achieve certain goals is a formal organization. The importance of building a school culture is primarily concerned with efforts to achieve school education goals and improve school performance. School culture illustrates how the entire academic community associates, acts, and solves problems in all matters in the school environment. The habit of developing themselves especially how each group member in the school tries to improve themselves and improve the quality of his work, is a culture that lives as a tradition that is no longer considered a workload. So is the case with supervision in an effort to improve the quality of learning, if it has been cultured, the teacher who implements it no longer considers that coaching is not a force that comes from outside himself. But the academic tradition is upheld because it is useful for the school as a whole.

School culture refers to a system of shared life that is believed to be the norm or behavioral patterns that are followed together. Culture is a guide to how each member of the school should be dealt with. School culture is a variable that influences how group members act and behave. Culture is a behavioral grip of all its members. The Ministry of National Education itself has the motto of Tutwuri Handayani, Ing. Mangun karso, Ing ngarso sung tulodo ".

It is this school culture that fosters how quality and performance are carried out by its members. How habits work to improve themselves is felt as part of his life. School culture in relation to the creation of satisfaction of the parties served is very important, because every school personnel feel selfimprovement and self-improvement is no longer coercive that comes from the supervisor as a coaching, but is felt as an integral part of having to solve work problems for student satisfaction. It is this school culture that fosters how quality and performance are carried out by its members. How habits work to improve themselves is felt as part of his life. School culture in relation to the creation of satisfaction of the parties served is very important, because every school personnel feel 
self-improvement and self-improvement is no longer coercive that comes from the supervisor as a coaching, but is felt as an integral part of having to solve work problems for student satisfaction

It is this school culture that hosts how quality and performance are carried out by its members. How habits work to improve themselves is felt as part of his life. School culture in relations to the creation of satisfaction from the parties served is very important, because every school personnel feel self-improvement and self-improvement is no longer coercive that comes from the supervisor as a coaching, but is felt as an integral part of having to solve work problems for student satisfaction. It is this school culture that hosts how quality and performance are carried out by its members. How habits work to improve themselves is felt as part of his life. School culture in relations to the creation of satisfaction from the parties served is very important, because every school personnel feel self-improvement and self-improvement is no longer coercive that comes from the supervisor as a coaching, but is felt as an integral part of having to solve work problems for student satisfaction. It is this school culture that hosts how quality and performance are carried out by its members. How habits work to improve themselves is felt as part of his life. School culture in relations to the creation of satisfaction from the parties served is very important, because every school personnel feel self-improvement and self-improvement is no longer coercive that comes from the supervisor as a coaching, but is felt as an integral part of having to solve work problems for student satisfaction. It is this school culture that hosts how quality and performance are carried out by its members. How habits work to improve themselves is felt as part of his life. School culture in relations to the creation of satisfaction from the parties served is very important, because every school personnel feel self-improvement and self-improvement is no longer coercive that comes from the supervisor as a coaching, but is felt as an integral part of having to solve work problems for student satisfaction.

\section{A. Problem Formulation}

Based on the above background then the formulation of the problem in this research is how does the school principal's academic supervision affect the teaching performance of the teacher at the Santo Yosef Junior High School in Surabaya? What is the influence of the School culture on the teaching performance of teachers at the Santo Yosef Middle School in Surabaya? What is the effect of the principal's academic supervision and school culture on the teaching performance of teachers at the Santo Yosef Junior High School in Surabaya?

\section{B. Research Objectives}

The poor academic performance of students in secondary schools has been a source of great concern to all stakeholders in the education sector. So it is to obtain information about the effect of the principal's academic supervision on the teaching performance of teachers at the Santo Yosef Middle School in Surabaya, to obtain information about the influence of school culture on teacher teaching performance at the Santo Yosef Junior High School in Surabaya, to obtain information about how much influence the school principal's academic supervision and school culture have on the teaching performance of teachers at the Santo Yosef Middle School in Surabaya Teacher Teaching Performance [3] reveals that the term performance comes from the word job performance or actual performance (work performance or actual achievement achieved by someone). This means that performance is the work of quality and quantity achieved by an employee in carrying out his duties in accordance with the responsibilities given to him.

\section{School Culture}

Not much different from the organization, the school also has its own culture as an identity that is imaged by the school. The thing that distinguishes between organizational culture and school culture lies in the goals to be achieved by the school, namely the purpose of education. Deal and Peterson [4] define school culture as follows: "Definition of the school culture: the values, culture, safety practices, and organizational values

Paterson [5] reveals about school culture as follows "deep pattens of values, beliefs, and traditions that have formed over the course of (the school's) history." Over time, a leader school can in conjunciton with other values and beliefs, astounding ones, or modifying elements that need to be changed.

\section{METHOD}

The causal relationship between the variable of Academic Supervision of Principals, School Culture, and Teaching Performance Teachers are assessed through the following stages: (1) development of research instruments for each variable followed by trials to test the validity and reliability of the instruments used for research data collection; (2) data collection carried out by distributing instruments to a set number of samples; and (3) data analysis, namely data processing using statistical techniques to test the research hypothesis and reveal the meaning contained in the results of testing the hypothesis.

The procedure of data collection is the stages through which the author in collecting research data, the procedure of data collection of this research is taken in three stages, namely: (1) Preparation Phase; (2) Trial Data Collection Tool; (3) Data processing. Data processing techniques or data analysis are part of the process of testing data, the results of which are used as sufficient evidence to draw research conclusions, so that the results provide convincing evidence, researchers use statistical techniques to analyze research data [6]. This study uses a quantitative approach, therefore the role of statistics in processing research data is very important. 
There are two types of statistics, namely descriptive statistics and inferential statistics. The statistics used in this study are descriptive statistics, where the use is to analyze data by describing or describing data that has been collected as it is without intending to make conclusions that apply to the general or generalizations [7].

Descriptive statistics in research are basically the process of transforming research data in tabulated form so that it is easily understood and interpreted. Tabulation presents a summary, arrangement or compilation of data in the form of numerical tables and graphs. Descriptive statistics are used to provide information about the characteristics of the research variables. The measurements used are mean or average. The use of descriptive statistics in this study was used to analyze descriptively as well.

\section{RESUlTS AND DISCUSSION}

\section{A. Principal Total Academic Supervision Score Analysis}

Based on the results of the calculation, the average value of the total teacher teaching performance is 48,6222 with a standard deviation of 15,5385 . The maximum theoretical value of teacher teaching performance for each respondent is $34 \times 5$ $=170$. The maximum value of teacher teaching performance is in fact 92 or $54.12 \%$ of the theoretical maximum value.

\section{B. Principal Total Academic Supervision Score Analysis}

Based on the results of the calculation, the average school supervisor's total academic supervision score is 62,644 with a standard deviation of 14.40826. the maximum theoretical value of the principal's academic supervision is $30 \times 5=150$. The maximum value of the school principal's academic supervision is in fact 88 or $58.66 \%$ of the theoretical maximum value. Total School Culture Score Analysis Based on the results of the above calculation, the total value of the total school culture is 65,444 with a standard deviation of 14.04628. The maximum theoretical value of school culture is $38 \times 5=190$. The maximum value of school culture is in fact 104. 54 , or $7368 \%$ of the theoretical maximum.

\section{Regression Analysis The Relationship between Teachers' Performance and Academic Supervision of Principals and School Culture}

Correlation between teacher teaching performance variables and school principals' academic supervision variables is 0.457 . it can be said that the correlation between teacher teaching performance variables and academic supervision is sufficient. Correlation between variables Teacher teaching performance and school culture variables are 0.724 . Then it can be said that the correlation between the variables of teaching performance and school culture is high. Regression Analysis The Relationship between Teachers' Performance and Academic Supervision of Principals and School Culture

Correlation between teacher teaching performance variables and school principals' academic supervision variables is 0.457 . it can be said that the correlation between teacher teaching performance variables and academic supervision is sufficient. Correlation between variables Teacher teaching performance and school culture variables are
0.724. Then it can be said that the correlation between the variables of teaching performance and school culture is high.

The correlation between the school supervisor's academic supervision variables and school culture variables is 0.514 . Then it can be said that the correlation between the variables of academic supervision and school culture is sufficient. The hypothesis states that: There is a positive and significant influence from the Principal Academic Supervision (X1), and School Culture (X2) variable on the Teacher Teaching Performance variable (Y), the findings are as follows:

\section{Effect of Principal Academic Supervision (X1) on Teacher Teaching Performance (Y)}

Supervision in the form of professional supervision is the supervision of the implementation of educational technical activities in schools, not just supervision of physical material. Principal Academic Supervision is supervision of academic activities in the form of teaching and learning processes, supervision of teachers in teaching, supervision of students who learn and supervision of situations that cause it. The activity is carried out by identifying the weaknesses of learning to be improved, what causes it, and why the teacher does not succeed in carrying out his duties properly. Based on this, follow-up was carried out in the form of improvements in the form of guidance. Coaching is a service to teachers in improving their performance. Coaching in addition to service to teachers, is also a preventive effort to prevent teachers from repeating themselves through doing similar misconducts that are not necessary, arousing their awareness in order to enhance their skills and teaching skills [8].

The results of the hypothesis test stated above indicate that the sub-variables of Academic Supervision (X1) have a positive influence on the sub-variables of Teacher Teaching Performance $(\mathrm{Y})$. with a correlation of 0.453 . the influence between variables is expressed by the coefficient of determination ( $\mathrm{r} 2$ ) which is equal to $0.4222=0.1781$ or $17.81 \%$. The resulting regression has an $\mathrm{R}$ square value of 0.178 , which gives the meaning that the teacher's teaching performance variable is influenced by the variable of academic supervision the principal is $17.8 \%$. there is a value of $82.2 \%$ influenced by other variables not defined in this study. The magnitude of the Standard error of the estimation is equal to 14.11416 which is quite small which means that the data obtained from this study is sufficiently fit for the resulting regression.

The F test value of the regression is 9,088 with the Sig of F change value of 0.004 indicating that together the principal's academic supervision variables and school culture affect the teacher's teaching performance variables. The value of the regression coefficient can be seen in table 4.16. The value of tstatistic for the school principal's academic supervision variable is 3.015 with negligible 0.004 (smaller than 5\%) meaning that the variable significantly influences the teacher's teaching performance variable

In conclusion: The research hypothesis states "There is a positive and significant effect of the Principal Academic Supervision variable (X1), on the Teacher Teaching 
Performance variable (Y)" the influence is $17.8 \%$. Effect of School Culture (X2) on Teacher Teaching Performance (Y)

The school culture applied by a school requires its members to adjust to the school culture which is a characteristic of a school. Each prospective member who will enter, is required to adjust to the culture that is in school. At that time the selection system also applies. This is intended so that prospective members who will enter the school are the right people according to the needs of a particular school.

The school culture adopted by teachers at Santo Yosef Surabaya Middle School is a means to improve the performance of teaching teachers and other employees. Increasing teacher teaching performance is the result of teacher internalization of school cultural values so that it raises high loyalty and commitment to the school which in turn has an impact on improving teacher teaching performance.

The results showed a correlation between teacher teaching performance variables and the school culture variable was 0.725 . it can be said that the correlation between teacher teaching performance variables and academic supervision is high. The resulting regression has an $\mathrm{R}$ square value of 0.360 , which gives the meaning that the teacher's teaching performance variable is influenced by the principal's academic supervision variable of $36 \%$. there is a value of $64 \%$ influenced by other variables not defined in this study. The magnitude of the Standard error of the estimation is 12.58712 which means that the data obtained from this study is sufficiently fit for the resulting regression.

\section{E. Effect of Principal Academic Supervision (X1) and School Culture (X2) on Teacher Teaching Performance (Y)}

Based on the results of calculations, it was found that the correlation between the school supervisor's academic supervision variables and the school culture variable was 0.514 . Then it can be said that the correlation between the variables of academic supervision and school culture is sufficient.

The resulting regression has a $\mathrm{R}$ square value of 0.356 , which gives the meaning that the teacher's teaching performance variables are influenced by school culture variables and the school supervisor's academic supervision variable is $35.6 \%$. there is a value of $64.4 \%$ influenced by other variables not defined in this study. The magnitude of the Standard error of the estimation is 12.64382 which is small enough which means that the data obtained from this study is sufficiently fit for the resulting regression.

The F test value of the regression is 11.330 with the Sig of $F$ change value of 0.000 indicating that together the principal's academic supervision and school culture variables affect the teacher's teaching performance variable

Value of regression coefficient can be seen in table 4.11 . The value of t-statistic for the variable of school principals' academic supervision is 0.161 with a negligence of 0.873 (smaller than 5\%), meaning that the variable significantly influences the teacher's teaching performance variable. Whereas for the school culture variable has a value of $t$ equal to 0.557 at alpha 0.581 (smaller than $5 \%$ ), meaning that the school culture variables affect the teacher's teaching performance variables significantly. Thus the regression equation form is: Teacher's teaching performance $=5,338+$ 0,029 academic supervision of the principal $+0,628$ school culture

This regression means that if the school principal's academic supervision scores up one unit then the teacher's teaching performance will increase by 0.029 units. and if the school's cultural values rise by one unit, the teacher's teaching performance value will increase by 0.628 units. in this regression the contribution of school culture variables to teacher teaching performance variables is greater than the school principal's academic supervision variable.

Teacher teaching performance variables are influenced by school culture variables and the school supervisor's academic supervision variable is accepted at $35.6 \%$. there is a value of $64.4 \%$ influenced by other variables not defined in this study. The magnitude of the Standard error of the estimation is 15,045 which is quite small which means that the data obtained from this study is quite fit for the resulting regression. The value of $\mathrm{F}$ test from regression is 8.148 with the Sig of F change value of 0.001 indicating that together the principal's academic supervision and school culture variables are proven to affect the teacher's teaching performance variables. Effect of Principal Academic Supervision (X1) and School Culture (X2) on Teacher Teaching Performance (Y)

Based on the results of calculations, it was found that the correlation between the school supervisor's academic supervision variables and the school culture variable was 0.514 . Then it can be said that the correlation between the variables of academic supervision and school culture is sufficient.

The resulting regression has a $\mathrm{R}$ square value of 0.356 , which gives the meaning that the teacher's teaching performance variables are influenced by school culture variables and the school supervisor's academic supervision variable is $35.6 \%$. there is a value of $64.4 \%$ influenced by other variables not defined in this study. The magnitude of the Standard error of the estimation is 12.64382 which is small enough which means that the data obtained from this study is sufficiently fit for the resulting regression.

The F test value of the regression is 11.330 with the Sig of F change value of 0.000 indicating that together the principal's academic supervision and school culture variables affect the teacher's teaching performance variable

Value of regression coefficient can be seen in table 4.11. The value of t-statistic for the variable of school principals' academic supervision is 0.161 with a negligence of 0.873 (smaller than 5\%), meaning that the variable significantly influences the teacher's teaching performance variable. Whereas for the school culture variable has a value of $t$ equal to 0.557 at alpha 0.581 (smaller than $5 \%$ ), meaning that the school culture variables affect the teacher's teaching performance variables significantly. Thus the regression equation form is: Teacher's teaching performance $=5,338+$ 0,029 academic supervision of the principal $+0,628$ school culture 
This regression means that if the school principal's academic supervision scores up one unit then the teacher's teaching performance will increase by 0.029 units. and if the school's cultural values rise by one unit, the teacher's teaching performance value will increase by 0.628 units. in this regression the contribution of school culture variables to teacher teaching performance variables is greater than the school principal's academic supervision variable.

Teacher teaching performance variables are influenced by school culture variables and the school supervisor's academic supervision variable is accepted at $35.6 \%$. there is a value of $64.4 \%$ influenced by other variables not defined in this study. The magnitude of the Standard error of the estimation is 15,045 which is quite small which means that the data obtained from this study is quite fit for the resulting regression. The value of $F$ test from regression is 8.148 with the Sig of F change value of 0.001 indicating that together the principal's academic supervision and school culture variables are proven to affect the teacher's teaching performance variables.

It was the duty of the principal to plan and organize for teaching demonstration and not oblige to do all the teaching [9]. Although experienced teachers or experts in various fields could take the principals' initiated demonstration, it was advised that he should have expert knowledge at least in two of the commonly taught subjects and also have a broad understanding of the current methodologies of teaching if he/she desired improvement from teachers. There is research [10] which aimed at determining the perception of teachers and actual performance of principal's supervisory responsibilities. He found that among teachers, who were asked to respond on how supervisors provided them the opportunity to watch demonstration lessons at least once in a term, $84 \%$ of them wished to be given the opportunity again, meaning that such a thing was uncommon in our schools.

\section{CONCLUSION}

Academic supervision of the principal gives a positive and significant influence with the average number of questionnaires sufficiently influencing the teacher's teaching performance. School culture has a positive and significant influence with the average number of questioners having a high influence on teacher teaching performance. although it is not the only factor that influences teacher teaching performance, school culture is a greater factor influencing teacher teaching performance compared to the principal's academic supervision variable. Academic supervision and school culture have an influence with sufficient criteria on teacher teaching performance; it means there are still many other factors that influence the teaching performance of the teacher in the program are compensation, work environment, facilities and infrastructure, technology, values, health status, and minimum wage level.

\section{REFERENCES}

[1] W. Surakhmad, Pendidikan nasional, strategi, dan tragedi. Penerbit Buku Kompas, 2009.

[2] D. Satori and A. Komariah, "Model of Management Capacity Building for Improving the Quality of School," J. Educ. Learn., vol. 9, no. 4, pp. 328-333, 2015.

[3] A. A. Mangkunegara, "Anwar Prabu, Evaluasi Kinerja SDM, Bandung: PT Refika Aditema, Cet," $\mathrm{Ke}-10,2006$.

[4] T. E. Deal and K. D. Peterson, "The Principal's Role in Shaping School Culture.," 1990.

[5] L. Paterson, "Scottish education in the twentieth century," 2004.

[6] I. Nur and B. Supomo, "Metodologi penelitian bisnis untuk akuntansi dan manajemen," Yogyakarta BPFE, 2002.

[7] Sugiyono, Metode Penelitian Kuantitatif, Kualitatif dan R\&D. Bandung: Alfabeta, 2012.

[8] M. Tschannen-Moran, Trust matters: Leadership for successful schools. John Wiley \& Sons, 2014.

[9] S. DA, Educating the reflective practitioner: Towards a new design for teaching and learning in the professions. San Fransisco: Jossey - Bass, 2000.

[10]Foster KP, "Supervisory behavior and teachers' satisfaction," J. Educ. Adm., vol. 18, no. 2, pp. 224-237, 1990. 